\title{
Apparent digestibility coefficients of selected protein ingredients for pirarucu Arapaima gigas (Teleostei: Osteoglossidae)
}

\author{
Ana Paula Oeda Rodrigues ${ }^{1}$, Giovanni Vitti Moro ${ }^{1}$, Viviane Rodrigues Verdolin dos Santos ${ }^{1}$ \\ Luiz Eduardo Lima de Freitas ${ }^{1} \&$ Débora Machado Fracalossi ${ }^{2}$ \\ ${ }^{1}$ Empresa Brasileira de Pesquisa Agropecuária, Embrapa Pesca e Aquicultura \\ Palmas, TO, Brazil \\ ${ }^{2}$ Departamento de Aquicultura, Centro de Ciências Agrárias, Universidade Federal \\ de Santa Catarina, Florianópolis, SC, Brazil \\ Corresponding author: Ana Paula Oeda Rodrigues (anapaula.rodrigues@embrapa.br)
}

\begin{abstract}
Apparent digestibility coefficients (ADCs) of nine protein ingredients were determined for pirarucu Arapaima gigas, a Neotropical fish species with great aquaculture potential in the Amazon. ADCs of crude protein, energy and dry matter were determined by feces sedimentation in cylindrical-conical tanks. Experimental diets were composed of $795 \mathrm{~g} \mathrm{~kg}^{-1}$ of the reference diet, $5 \mathrm{~g} \mathrm{~kg}^{-1}$ of chromic oxide and $200 \mathrm{~g} \mathrm{~kg}^{-1}$ of the following test ingredients: fish by-product meal, salmon by-product meal, poultry by-product meal, hydrolyzed feather meal, meat and bone meal, blood meal, soybean meal, corn gluten meal and corn gluten feed. Blood meal, meat and bone meal and corn gluten feed resulted in low ADCs for pirarucu, whereas corn gluten meal, poultry by-product meal and soybean meal were better digested, indicating that these ingredients may be potential protein sources in feed formulations for pirarucu. The other animal protein ingredients presented intermediate ADCs values and, together with blood meal and meat and bone meal, they demonstrate that the nutritional quality of the animal by-products tested could be improved, especially by enhancing the processing methods of this group of ingredients.
\end{abstract}

Keywords: Arapaima gigas; proteins; diet formulation; feed availability; fish meal; aquaculture

\section{INTRODUCTION}

Pirarucu Arapaima gigas (Osteoglossomorpha: Osteoglossidae) is a large carnivorous fish species of high commercial value and great aquaculture potential in the Amazon region. Its excellent meat quality and unique fast growth among freshwater fish species (up to $10 \mathrm{~kg}$ in the first year) are some of the characteristics that make pirarucu a very attractive species for aquaculture (Lima et al., 2015). However, many technological limitations hinder the development of commercial farming of pirarucu (Lima et al., 2015), in particular, limited knowledge on the nutrition in captivity.

Nutrition should be essentially species-specific, considering the physiological and behavioral singularities of each fish species, with little generalizations (Cyrino et al., 2010). For pirarucu, few studies in fish nutrition have been conducted. Limited information on nutritional requirements and ingredients digestibilities is available for the species (e.g., Ituassú et al., 2005; Del Risco et al., 2008; Santos-Cipriano et al., 2015; Cipriano et al., 2016), and those are essential for the development of balanced and efficient feeds for the adequate production of pirarucu (Cho et al., 1985; Glencross et al., 2007). Additionally, with increasing demand for protein ingredients to replace fish meal, studies on digestibility and potentiality of such alternative ingredients are even more necessary for the sustainability of the aquaculture industry, specially of carnivorous fish species (Glencross et al., 2007; Tacon \& Metian, 2008; Naylor et al., 2009). In Brazil, such need is increased by the low quality of the fish meals (Lima et al., 2014), and on the other hand, by the plenty availability of agriculture by-products with potential use in aquaculture (Melo \& Nikolik, 2013; Fontes et al., 2016). This study determined the apparent digestibility

Corresponding editor: Patricio Dantagnan 
of nine protein ingredients for juvenile pirarucu to provide a basis for the development of more adequate feeds for the species. The selection of the test ingredients considered those ingredients conventionally employed in diet formulation by the aquafeed industry.

\section{MATERIALS AND METHODS}

\section{Diet formulation and manufacture}

The digestibility of nine protein ingredients was assessed for pirarucu in a randomized block design (three replicates ran over time). The reference diet was formulated based on pirarucu's protein requirement (Ituassu et al., 2005; Del Risco et al., 2008); other nutrients were estimated based on the information available for other freshwater carnivorous fish species (NRC, 2011) (Table 1). Test ingredients were previously ground and sieved through a $600-\mu \mathrm{m}$ mesh hammer mill (MX 80 Imbramaq, Brazil).

For the experimental diets, the dry ingredients were blended in a mixer (BP-20C, G. Paniz, Brazil), and later linseed oil and water (140-180 $\mathrm{g} \mathrm{kg}^{-1}$ ) were added. The mixture was extruded at $150^{\circ} \mathrm{C}$ through a $4.5 \mathrm{~mm}$ die (MX-40, Imbramaq, Brazil), and pellets were dried in a forced air oven at $55^{\circ} \mathrm{C}$.

Experimental diets were stored at $-21^{\circ} \mathrm{C}$ and weekly allowance was kept at $4^{\circ} \mathrm{C}$. Experimental diets were composed of $795 \mathrm{~g} \mathrm{~kg}^{-1}$ of the reference diet, $200 \mathrm{~g} \mathrm{~kg}^{-1}$ of the test ingredient and $5 \mathrm{~g} \mathrm{~kg}^{-1}$ of chromic oxide. In digestibility trials, ingredients are usually combined with basal diets in a 70:30 ratio as was first suggested by Cho \& Slinger (1979) who applied this ratio to simulate feed inclusion levels in practical diets. However, any proportion can be used as long as the fish can consume the diet, and the proportions ensure the normal digestion process (NRC, 2011). Glencross et al. (2007) recommend inclusion levels from 20 to $40 \%$ for the test ingredients to simulate the levels used in practical diets. In this study, the 80:20 ratio was chosen to ensure the experimental diets remained as close as possible of the nutritional composition of the reference diet, and, therefore, to minimize differences in fish consumption due to the inclusion level of the test ingredient.

The test ingredients were: fish by-product meal (IFN 5-14-509), salmon by-product meal (IFN 5-02012), poultry by-product meal (IFN 5-03-798), hydrolyzed feather meal (IFN 5-03-795), meat and bone meal (IFN 5-00-388), blood meal (disc dried; IFN 5-00-380), soybean meal (IFN 5-04-604), corn gluten meal (IFN 5-02-900), and corn gluten feed (IFN 5-02903) (Table 2). The general processing methods and
Table 1. Feed ingredients and proximate composition of

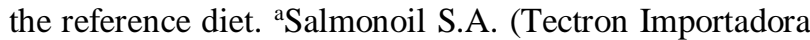
e Exportadora de produtos Veterinários Ltda., Toledo, PR, Brasil). ${ }^{b} \mathrm{NaH}_{2} \mathrm{PO}_{4} 454 \mathrm{~g} \mathrm{~kg}^{-1} ; \mathrm{K}_{2} \mathrm{SO}_{4} 297 \mathrm{~g} \mathrm{~kg}^{-1} ; \mathrm{NaCl} 174$ $\mathrm{g} \mathrm{kg}^{-1} ; \mathrm{MgSO}_{4} 75 \mathrm{~g} \mathrm{~kg}^{-1}$. 'Composition per kg of premix: folic acid $250 \mathrm{mg}$; pantothenic acid 5,000 mg; antioxidant $0.6 \mathrm{~g}$; biotin $50 \mathrm{mg}$; Co $25 \mathrm{mg}$; $\mathrm{Cu} 2,000 \mathrm{mg}$; choline 75,000 mg; Fe 13,750 mg; I 100 mg; Mn 3,750 mg; niacin $5,000 \mathrm{mg}$; Se $75 \mathrm{mg}$; vitamin A 1,000,000 IU; vitamin B1 $500 \mathrm{mg}$; vitamin B12 3,750 mg; vitamin B2 $1,750 \mathrm{mg}$; vitamin B6 1,125 mg; ascorbic acid 42,000 mg; vitamin D3 500,000 IU; vitamin E 20,000 IU; vitamin K3, $500 \mathrm{mg}$; Zn 20,000 mg.

\begin{tabular}{lc}
\hline Ingredients & $\begin{array}{c}\text { Inclusion level } \\
\left(\text { dry matter; } \mathrm{g} \mathrm{kg}^{-1}\right)\end{array}$ \\
\hline Salmon by-product meal ${ }^{\mathrm{a}}$ & 597.00 \\
Corn & 315.40 \\
Macromineral mixture $^{\mathrm{b}}$ & 54.73 \\
Vitamin and micromineral premix $^{\mathrm{c}}$ & 14.93 \\
Linseed oil $_{\text {Chromic oxide }}$ & 12.94 \\
\hline Proximate composition & 5.00 \\
\hline Dry matter & \\
Crude protein & 940.50 \\
Ether extract & 487.50 \\
Neutral detergent fiber & 97.90 \\
Ash & 34.30 \\
Gross energy $\left(\mathrm{kJ} \mathrm{g}^{-1}\right)$ & 170.90 \\
\end{tabular}

characterization of these ingredients are described by Tacon et al. (2009).

\section{Fish handling and fecal collection}

Juvenile pirarucus weighing $c a .8 .5 \mathrm{~g}$ were purchased from a commercial hatchery (Senador La Roque, MA, Brazil). Fish were previously acclimated in 1,000 L circular tanks for approximately three months with a commercial feed (2-4 mm; $450 \mathrm{~g} \mathrm{~kg}^{-1}$ of crude protein; Laguna, Socil, Descalvado, SP). For the digestibility trial, fish were distributed in ten 200-L cylindricalconical tanks at a density of 10 fish per tank, compounding total mean biomass of 2,044.5 $\pm 70.0 \mathrm{~g}$ $\operatorname{tank}^{-1}$. Fish were kept in a recirculated water system under controlled temperature $\left(27.91 \pm 0.82^{\circ} \mathrm{C}\right)$ and were initially acclimated to the experimental units for 12 days, receiving the same commercial feed during this period. At the end of this acclimation time, treatments were randomly distributed in the 10 tanks. New treatment randomization in the tanks $(\mathrm{n}=10)$ was performed at each replication, run over time (three replicates on time). Before collecting feces, fish were adapted for five days to the experimental diets (Blyth et al., 2015). Fish were fed twice a day (08:30 and 14:00 h) to apparent satiation (which corresponded to around 
Table 2. Proximate composition of the protein ingredients tested (dry matter basis). nd: not determined.

\begin{tabular}{lcccccc}
\hline Ingredients & $\begin{array}{c}\text { Dry matter } \\
\left(\mathrm{g} \mathrm{kg}^{-1}\right)\end{array}$ & $\begin{array}{c}\text { Crude protein } \\
\left(\mathrm{g} \mathrm{kg}^{-1}\right)\end{array}$ & $\begin{array}{c}\text { Ether extract } \\
\left(\mathrm{g} \mathrm{kg}^{-1}\right)\end{array}$ & $\begin{array}{c}\text { Ash } \\
\left(\mathrm{g} \mathrm{kg}^{-1}\right)\end{array}$ & $\begin{array}{c}\text { Neutral detergent fiber } \\
\left(\mathrm{g} \mathrm{kg}^{-1}\right)\end{array}$ & $\begin{array}{c}\text { Energy } \\
\left(\mathrm{kJ} \mathrm{g} \mathrm{g}^{-1}\right)\end{array}$ \\
\hline Corn gluten meal & 927.3 & 813.1 & 82.5 & 7.9 & 20.44 & 24.83 \\
Soybean meal & 897.7 & 520.4 & 27.2 & 66.4 & 8.69 & 20.52 \\
Salmon by-product meal & 896.1 & 706.4 & 111.9 & 172.2 & nd & 20.52 \\
Poultry by-product meal & 948.6 & 676.4 & 168.6 & 146.5 & nd & 21.77 \\
Hydrolyzed feather meal & 939.7 & 908.5 & 93.6 & 26.4 & nd & 24.03 \\
Fish by-product meal & 939.9 & 579.5 & 131.8 & 292.6 & nd & 18.09 \\
Corn gluten feed & 853.5 & 213.2 & 44.9 & 71.2 & 39.48 & 19.47 \\
Meat and bone meal & 938.8 & 439.4 & 167.6 & 395.1 & nd & 15.66 \\
Blood meal & 867.0 & 931.8 & 31.2 & 37.3 & nd & 23.99 \\
\hline
\end{tabular}

25 to $35 \mathrm{~g} \mathrm{~kg}^{-1}$ of pirarucu body weight, daily). Approximately $30 \mathrm{~min}$ after feeding, bottom water from the tanks was flushed to ensure uneaten feed and feces were discarded and then proceed to feces collection. Most of the fecal material was collected in $50 \mathrm{~mL}$ settling tubes attached to the bottom of the tanks (modified Guelph system). However, part of the pirarucu feces floated before settling, and these were collected with a net from the water surface. Each collection period lasted about two hours, and during this time the production of feces was continuously checked. Fish from the same tank used to defecate at the same time interval. Therefore, as soon as it was observed that the feces had settled or floated, they were immediately collected and frozen at $-20^{\circ} \mathrm{C}$ and then freeze-dried at $-50^{\circ} \mathrm{C}$ (L-101; Liotop, Brazil). Daily, after the afternoon feces collection, tank walls were cleaned, and approximately $70 \%$ of the water volume was exchanged to prevent excess bacterial growth on tank walls. Dissolved oxygen, $\mathrm{pH}$ and toxic ammonia were kept at $2.16 \pm 0.72 \mathrm{mg} \mathrm{L}^{-1}, 6.83 \pm 0.23$ and $<0.05$ $\mathrm{mg} \mathrm{L}^{-1}$, respectively, within the values, recommended for this air-breathing fish species (Pereira-Filho \& Roubach, 2010).

\section{Chemical and digestibility analysis}

Experimental diets, ingredients, and feces were analyzed according to AOAC (1999) for dry matter (method 930.15; Drying-Oven Edutec, Brazil), ash (method 942.05; Muffle furnace Sanchis, Brazil), crude protein (Nx6.25; method 988.05; Block digester 23/02, Lucadema, Brazil, and Nitrogen distiller TE-0363, Tecnal, Brazil) and ether extract (petroleum ether; method 920.39; Fat extractor TE-044, Tecnal, Brazil). Gross energy was measured by calorimetry (Model 6400, Parr Instrument Company, USA) and neutral detergent fiber (aNDFom) by the method of Van Soest et al. (1991) (Fiber Analyzer TE-149, Tecnal, Brazil).
Chromic oxide in the diets and feces was quantified by atomic absorption spectrometry (contrAA 700, Analytik Jena AG, Germany).

Apparent digestibility coefficients (ADCs) of crude protein, gross energy, and dry matter were determined by the following equations (Bureau et al., 1999):

For the diets:

$\operatorname{ADC}(\%)=100-[100 \times(\%$ marker in diet $/ \%$ marker in feces $) \times\left(\%\right.$ nutrient or $\mathrm{kJ} \mathrm{g}^{-1}$ of gross energy in feces / \% nutrient or $\mathrm{kJ} \mathrm{g} \mathrm{g}^{-1}$ of gross energy in diet)]

For the tested ingredients:

$$
\begin{gathered}
\mathrm{ADC}_{\mathrm{I}}=\mathrm{ADC}_{\mathrm{Td}}+\left[\left(\mathrm{ADC}_{\mathrm{Td}}-\mathrm{ADC}_{\mathrm{Ref}}\right) \times(0.8 \times\right. \\
\left.\left.\mathrm{N}_{\mathrm{Ref}} / 0.2 \times \mathrm{N}_{\mathrm{I}}\right)\right]
\end{gathered}
$$

where I: test ingredient; Td: test diet; Ref: reference diet; $\mathrm{N}_{\text {Ref: nutrient }}(\%)$ or gross energy $\left(\mathrm{kJ} \mathrm{g}^{-1}\right)$ in reference diet; $\mathrm{N}_{\mathrm{I}}$ : nutrient (\%) or gross energy $\left(\mathrm{kJ} \mathrm{g}^{-1}\right)$ in test ingredient.

\section{Statistical analysis}

ADCs data were submitted to analysis of variance, considering a randomized block design, followed by Tukey's test $(P<0.05)$ to detect statistical differences among means. Homoscedasticity and normality of residues were tested by applying Shapiro-Wilk and Levene tests, respectively $(P<0.05)$. Digestible protein and energy values were estimated by multiplying the protein and energy values of each ingredient with the respective average of the ADCs obtained.

\section{Ethical and legal aspects}

The experimental procedures were approved by the Animal Ethics Committee of Embrapa Pesca e Aquicultura (CEUA protocol 01/2014) and the National System for the Management of Genetic Heritage and Associated Traditional Knowledge (AA4F2B0). 


\section{RESULTS}

The ADC values for crude protein, gross energy, and dry matter of test ingredients are presented in Table 3, as well as the estimated digestible protein and energy values. Apparent protein digestibility of corn gluten meal and soybean meal were higher than that of meat and bone meal and blood meal, which, in turn, presented the lowest value $(P<0.05)$. Intermediate values were observed for the other ingredients, and they were not different from corn gluten meal, soybean meal and meat and bone meal $(P>0.05)$.

Apparent energy digestibility for pirarucu was higher for hydrolyzed feather meal in comparison to corn gluten feed and blood meal $(P<0.05)$. Corn gluten meal, soybean meal and poultry by-product meal presented energy ADCs values higher than 0.800 which were significantly higher than the energy ADC obtained for a blood meal. Salmon by-product meal, fish by-product meal, corn gluten feed meat and the bone meal did not differ from blood meal $(P>0.05)$.

Apparent dry matter digestibility, higher than 1,000, was observed for corn gluten meal and poultry byproduct meal. Blood meal presented the lowest apparent dry matter digestibility $(P<0.05)$, whereas the other ingredients presented intermediate values.

\section{DISCUSSION}

Blood meal was the test ingredient with the lowest ADCs for pirarucu, and that may be mainly related to the ingredient drying process (disc-drying), which can significantly affect its protein digestibility (Hajen et al., 1993; Zhou et al., 2008). Studies with several carnivorous fish species reported considerable variation in blood meal ADC values, varying from 0.237 to 0.929 for protein and from 0.319 to 0.862 for energy (Hajen et al., 1993; Zhou et al., 2008; Gaylord et al., 2010; Wang et al., 2012; Booth et al., 2013). Besides the ingredient processing method, this reflects differences among species and quality of the raw material ( $\mathrm{Yu}$ et al., 2013).

The low digestibility observed for meat and bone meal, particularly dry matter, may be attributed to high ash content (395.1 $\mathrm{g} \mathrm{kg}^{-1}$; Table 2) (Robaina et al., 1997; Bureau et al., 1999; Allan et al., 2000; Guimarães et al., 2008). Xavier et al. (2014) studied the digestibility of several types of meat and bone meal for Nile tilapia Oreochromis niloticus and reported reduced apparent dry matter digestibility with increased ash content and reduced protein levels.

Corn gluten feed is a by-product of the processing of corn, after the extraction of starch, gluten, and germ
(Tacon et al., 2009). Although it is often used in commercial feeds for omnivorous and carnivorous fish species due to its low cost, studies evaluating corn gluten feed for tropical fish species are still scarce. For the omnivorous channel catfish Ictalurus punctatus, the apparent crude protein digestibility for corn gluten feed was satisfactory (0.881) whereas the ADCs for gross energy (0.423) and dry matter (0.393) exhibited low values (Kitagima \& Fracalossi, 2011). Vidal et al. (2015) also observed such trend of high ADC for crude protein (0.912) and low for energy (0.590) and dry matter $(0.563)$ when testing this ingredient for Nile tilapia. In the present study, protein digestibility of corn gluten feed for pirarucu was lower in comparison to the values obtained for channel catfish and Nile tilapia. However, pirarucu also exhibited relatively low ADCs for gross energy and dry matter. Such results found for pirarucu, channel catfish, and Nile tilapia might be due to the high fiber content of corn gluten feed; a dietary component that can reduce energy digestibility (Rodrigues et al., 2012).

Protein digestibility of fish by-product meal was lower than those reported in other studies testing Brazilian fish meals with similar or even higher ash content (260-340 $\mathrm{g} \mathrm{kg}^{-1}$ ) (Gonçalves \& Carneiro, 2003; Abimorad et al., 2008; Guimarães et al., 2008; Kitagima \& Fracalossi, 2011). Nevertheless, energy digestibility did not differ so markedly, probably reflecting the high lipid level of the fish meal tested for pirarucu (132 $\mathrm{g} \mathrm{kg}^{-1}$; Table 2); which was mainly composed of fish processing waste rich in fish viscera explaining the high-fat level in the resulting fish meal. Salmon by-product meal, commercially used in Brazilian starter feeds for carnivorous fish, was assessed in the present study to be compared to the fish by-product meal produced in Brazil and it presented higher ADC values for protein and dry matter, possibly because of better nutritional quality (lower ash content and, consequently, higher protein level). A similar trend was observed for Lutjanus guttatus (Hernández et al., 2015), a carnivorous marine species, and for hybrid striped bass (Morone chrysops $\times$ M. saxatilis) and rainbow trout Oncorhynchus mykiss (Bowzer et al., 2015) when comparing fish meals with different ash contents. In contrast to the low nutritional quality and digestibility of the fish by-product meal, corn gluten meal, poultry by-product meal and soybean meal were well digested by pirarucu, indicating that they may be potential protein sources in feed formulations for pirarucu.

Likewise, other studies reported the good utilization of corn gluten meals for omnivorous fish species such as silver perch Bidyanus bidyanus (Allan et al., 2000), jundiá Rhamdia quelen (Oliveira-Filho \& Fracalossi, 
Table 3. Apparent digestibility coefficients (ADCs) of protein ingredients for pirarucu Arapaima gigas and their respective digestible values of protein and energy (mean \pm standard deviation). Different superscripts letters in the same row indicate different means by Tukey's test $(P<0.05)$.

\begin{tabular}{|c|c|c|c|c|c|}
\hline Ingredients & $\begin{array}{l}\text { ADC crude } \\
\text { protein }(\%)\end{array}$ & $\begin{array}{l}\text { ADC gross } \\
\text { energy }(\%)\end{array}$ & $\begin{array}{l}\text { ADC dry } \\
\text { matter (\%) }\end{array}$ & $\begin{array}{c}\text { Digestible } \\
\text { protein }\left(\mathrm{g} \mathrm{kg}^{-1}\right)\end{array}$ & $\begin{array}{c}\text { Digestible } \\
\text { energy }\left(\mathrm{kJ} \mathrm{g}^{-1}\right)\end{array}$ \\
\hline Corn gluten meal & $0.935 \pm 0.015^{\mathrm{a}}$ & $0.878 \pm 0.066^{\mathrm{ab}}$ & $1.024 \pm 0.034^{\mathrm{a}}$ & 759.89 & 21.79 \\
\hline Soybean meal & $0.924 \pm 0.008^{\mathrm{a}}$ & $0.837 \pm 0.063^{\mathrm{ab}}$ & $0.790 \pm 0.053^{\mathrm{ab}}$ & 480.73 & 17.16 \\
\hline Salmon by-product meal & $0.839 \pm 0.037^{\mathrm{ab}}$ & $0.756 \pm 0.087^{\mathrm{abc}}$ & $0.836 \pm 0.076^{\mathrm{ab}}$ & 592.69 & 15.50 \\
\hline Poultry by-product meal & $0.836 \pm 0.042^{\mathrm{ab}}$ & $0.857 \pm 0.023^{\mathrm{ab}}$ & $1.006 \pm 0.041^{\mathrm{a}}$ & 565.74 & 18.65 \\
\hline Hydrolyzed feather meal & $0.797 \pm 0.011^{\mathrm{ab}}$ & $0.911 \pm 0.114^{\mathrm{a}}$ & $0.795 \pm 0.156^{\mathrm{ab}}$ & 723.74 & 21.89 \\
\hline Fish by-product meal & $0.772 \pm 0.011^{\mathrm{ab}}$ & $0.761 \pm 0.142^{\mathrm{abc}}$ & $0.723 \pm 0.045^{\mathrm{b}}$ & 447.29 & 13.76 \\
\hline Corn gluten feed & $0.771 \pm 0.112^{\mathrm{ab}}$ & $0.639 \pm 0.088^{b c}$ & $0.659 \pm 0.198^{b c}$ & 164.32 & 12.45 \\
\hline Meat and bone meal & $0.720 \pm 0.060^{\mathrm{b}}$ & $0.701 \pm 0.074^{\mathrm{abc}}$ & $0.624 \pm 0.062^{\mathrm{bc}}$ & 316.19 & 10.98 \\
\hline Blood meal & $0.386 \pm 0.122^{\mathrm{c}}$ & $0.560 \pm 0.110^{c}$ & $0.421 \pm 0.158^{c}$ & 359.28 & 13.43 \\
\hline
\end{tabular}

2006), pacu Piaractus mesopotamicus (Abimorad et al., 2008), channel catfish (Kitagima \& Fracalossi, 2011) and Nile tilapia (Vidal et al., 2015), as well as for carnivorous species, such as cobia Rachycentron canadum (Zhou et al., 2004), dourado Salminus brasiliensis (Borghesi et al., 2009), Atlantic salmon Salmo salar (Burr et al., 2011) and Northern snakehead Ophiocephalus argus (Yu et al., 2013), showing protein and energy ADCs values ranging from 0.856 to 0.968 and from 0.827 to 1.045 , respectively. However, low palatability (Park et al., 1997; Cha et al., 2000; Bicudo et al., 2012), imbalance in essential amino acids (Mente et al., 2003; Abimorad et al., 2008) and high price should also be assessed in future studies on the use of this ingredient for pirarucu.

ADC values for protein and energy in soybean meal for pirarucu were similar to those reported for other carnivorous freshwater and marine fish species (Glencross et al., 2004; Zhou et al., 2004; Tibbetts et al., 2006; Borghesi et al., 2009). Despite the high ADC values of soybean meal for pirarucu, the fecal material of fish fed soybean meal experimental diet was less consistent and more liquid when compared to those from other test diets. As feces were collected almost immediately after appearing in the settling tubes, nutrient losses by leaching might have been minimized. Atlantic salmon fed diets containing soybean meal presented feces with high water content and morphological alterations in the distal intestine (Refstie et al., 1999; Kraugerud et al., 2007). These responses were attributed to the antinutrients of soybean meal which affect nutrient digestion and absorption processes (Krogdahl et al., 2010). Therefore, further studies evaluating inclusion levels of soybean meal in feeds for pirarucu and its long-term effects are necessary.

Poultry by-product meal was the animal protein ingredient with the highest digestibility results for pirarucu, corroborating other studies with silver perch (Allan et al., 2000), rainbow trout (Bureau et al., 1999), Nile tilapia (Guimarães et al., 2008), striped surubim Pseudoplatystoma reticulatum (Silva et al., 2013) and Japanese seabass Lateolabrax japonicus (Wang et al., 2012). The high price of this ingredient should be considered in future studies, together with other aspects such as its high phosphorus and fat contents that can hinder water quality and favor feed oxidation, respectively (Guimarães et al., 2008; Kitagima \& Fracalossi, 2011).

Apparent protein digestibility of hydrolyzed feather meal for pirarucu was similar to those values reported for juvenile rockfish Sebastes schlegeli (0.790) (Lee, 2002) and Nile tilapia (0.785) (Guimarães et al., 2008), but lower to values reported for rainbow trout $(0.810$ 0.870) (Bureau et al., 1999) and channel catfish (0.898) (Kitagima \& Fracalossi, 2011). Protein and energy digestibility of hydrolyzed feather meal for pirarucu was higher than those reported for carnivorous freshwater surubim $P$. coruscans $(0.396$ and 0.513$)$ (Gonçalves \& Carneiro, 2003) and P. reticulatum (0.198 and 0.538) (Silva et al., 2013). Similar to blood meal and meat and bone meal, those differences mainly reflect the different processing methods (quality and freshness of the raw material, processing itself and storage) (Tibbetts et al., 2006).

Dry matter ADCs values higher than 1.000 for poultry by-product meal and corn gluten meal were also reported by Allan et al. (2000) for silver perch. This might have been due to errors during chemical analysis of the marker and nutrients, non-homogeneous mixing of the marker into the diets, interaction between the ingredients of the experimental diets and different leaching of the nutrients of the ingredient (Allan et al., 2000; Glencross et al., 2007; NRC, 2011). 
The apparent digestibility of corn gluten feed, hydrolyzed feather meal, fish by-product meal, meat and bone meal, poultry by-product meal and soybean meal were previously evaluated for pirarucu in pelletized diets by Cipriano et al. (2016). In comparison to the results found in this study, corn gluten feed and soybean meal (vegetable protein ingredients) presented lower ADCs, probably due to differences in the diet processing method. The extrusion process can potentially enhance plant proteins digestibility due to the higher temperatures achieved (NRC, 2011). Hydrolyzed feather meal exhibited similar digestibility for crude protein $(0.804)$ and dry matter $(0.795)$, despite the lower ADC for gross energy (0.833). Poultry byproduct meal, fish by-product meal, and meat and bone meal had higher ADCs which can be explained by differences in quality of the raw material and ingredient processing, as well as the lower ash content of the ingredients tested by Cipriano et al. (2016).

In the present study, corn gluten meal, poultry byproduct meal and soybean meal presented high digestibility and great potential to be included as protein sources in diets for pirarucu (Table 3 ). Although digestibility of animal protein ingredients has increased in many countries due to improved processing techniques (Bureau et al., 1999; Naylor et al., 2009), based on the results observed for pirarucu and other Neotropical fish species, nutritional quality of such ingredients, including fish by-product meal, is still low and variable. Therefore, it is important that studies focusing on improving feed formulation for the Brazilian aquaculture also include the systematic and continuous assessment of the quality of the raw materials for animal proteins.

\section{ACKNOWLEDGMENTS}

The authors are thankful to Nicoluzzi Rações and Kabsa S.A. for providing most of the experimental ingredients. The present study is part of the "Pirarucu da Amazônia Project - Research and Technology Transfer" (Projeto Pirarucu-da-Amazônia - Pesquisa e Transferência de Tecnologias). Funded by Brazilian Support Service for Micro and Small Companies (SEBRAE) through the Tocantins Research Foundation (FAPTO agreement 9/2012, grant $\mathrm{N}^{\circ} 2538 / 2012$ ) and Ministry of Agriculture, Livestock and Food Supply through the National Council for the Scientific and Technological Development (CNPq grant $\mathrm{N}^{\circ} 434.400$ / 2016-5). Thanks are also due to CNPq for the research fellowship granted to the last author.

\section{REFERENCES}

Abimorad, E.G., Squassoni, G.H. \& Carneiro, D.J. 2008. Apparent digestibility of protein, energy, and amino acids in some selected feed ingredients for pacu Piaractus mesopotamicus. Aquaculture Nutrition, 14: 374-380.

Allan, G.L., Parkinson, S., Booth, M.A., Stone, D.A.J., Rowland, S.J., Frances, J. \& Warner-Smith, R. 2000. Replacement of fish meal in diets for Australian silver perch, Bidyanus bidyanus: I. Digestibility of alternative ingredients. Aquaculture, 186: 293-310.

Association of Official Analytical Chemists (AOAC). 1999. Official methods of analysis. Association of Official Analytical Chemists, Washington D.C.

Bicudo, A.J.A., Borghesi, R., Dairiki, J.K., Sado, R.Y. \& Cyrino, J.E.P. 2012. Performance of juveniles of Pseudoplatystoma fasciatum fed graded levels of corn gluten meal. Pesquisa Agropecuária Brasileira, 47: 838-845.

Blyth, D., Tabrett, S., Bourne, N. \& Glencross, B. 2015. Comparison of fecal collection methods and diet acclimation times for the measurement of digestibility coefficients in barramundi (Lates calcarifer). Aquaculture Nutrition, 21: 248-255.

Booth, M.A., Allan, G.L. \& Smullen, R.P. 2013. Digestibility of common feed ingredients by juvenile mulloway Argyrosomus japonicas. Aquaculture, 414415: 140-148.

Borghesi, R., Dairiki, J.K. \& Cyrino, J.E.P. 2009. Apparent digestibility coefficients of selected feed ingredients for dourado Salminus brasiliensis. Aquaculture Nutrition, 15: 453-458.

Bowzer, J., Trushenski, J., Rawles, S., Gaylord, T.G. \& Barrows, F.T. 2015. Apparent digestibility of Asian carp- and common carp-derived fish meals in feeds for hybrid striped bass Morone saxatilis $\circ \times$ M. chrysops $\hat{\gamma}$ and rainbow trout Oncorhynchus mykiss. Aquaculture Nutrition, 21: 43-53.

Bureau, D.P., Harris, A.M. \& Cho, C.Y. 1999. Apparent digestibility of rendered animal protein ingredients for rainbow trout (Oncorhynchus mykiss). Aquaculture, 180: 345-358.

Burr, G.S., Barrows, F.T., Gaylord, G. \& Wolters, W.R. 2011. Apparent digestibility of macronutrients and phosphorus in plant-derived ingredients for Atlantic salmon, Salmo salar and Arctic charr, Salvelinus alpinus. Aquaculture Nutrition, 17: 570-577.

Cha, J.Y., Flores, R.A. \& Park, H. 2000. Reduction of carotenoids in corn gluten meal with soy flour. Transactions of the American Society of Agricultural Engineers, 43: 1169-1174.

Cho, C.Y. \& Slinger, S.J. 1979. Apparent digestibility measurement in feedstuffs for rainbow trout. In: Halver, J.E. \& Tiews, K. (Eds.). Finfish nutrition and fish feed technology. Proceeding of a World Symposium vol. 2. Heenemann, Berlin, pp. 239-247. 
Cho, C.Y., Cowey, C.B. \& Watanabe, T. 1985. Nutrition experimentation: approach and design. In: Cho, C.Y., Cowey, C.B. \& Watanabe, T. (Eds.). Finfish nutrition in Asia. Methodological approaches to research and development. International Development Research Centre (IDRC), Ottawa, pp. 69-76.

Cipriano, F.S., Lima, K.S., Souza, R.H.B., Tonini, W.C.T., Passinato, E.B. \& Braga, L.G.T. 2016. Digestibility of animal and vegetable protein ingredients by pirarucu juveniles, Arapaima gigas. Revista Brasileira de Zootecnia, 45: 581-586.

Cyrino, J.E.P., Bicudo, A.J.A., Sado, R.Y., Borghesi, R. \& Dairiki, J.K. 2010. A piscicultura e o ambiente - o uso de alimentos ambientalmente corretos em piscicultura. Revista Brasileira de Zootecnia, 39: 6887.

Del Risco, M., Velásquez, J., Sandoval, M., Padilla, P., Mori-Pinedo, L. \& Chu-Koo, F. 2008. Effects of three dietary protein levels on the growth of paiche, Arapaima gigas (Shinz, 1822) juveniles. FOLIA Amazónica, 17: 29-37.

Fontes, A., Nikolik, G., Rasmussen, R., Ikeda, V. \& Souza, I. 2016. Feeding nemo. Turning Brazil's economic turmoil into seafood business opportunities. Rabobank Industry Note, 564: 1-8.

Gaylord, T.G., Barrows, F.T. \& Rawles, S.D. 2010. Apparent amino acid availability from feedstuffs in extruded diets for rainbow trout (Oncorhynchus mykiss). Aquaculture Nutrition, 16: 400-406.

Glencross, B.D., Booth, M. \& Allan, G.L. 2007. A feed is only as good as its ingredients - a review of ingredient evaluation strategies for aquaculture feeds. Aquaculture Nutrition, 13: 17-34.

Glencross, B.D., Carter, C.G., Duijster, N., Evans, D.R., Dods, K., McCafferty, P., Hawkins, W.E., Maas, R. \& Sipsas, S. 2004. A comparison of the digestibility of a range of lupin and soybean protein products when fed to either Atlantic salmon (Salmo salar) or rainbow trout (Oncorhynchus mykiss). Aquaculture, 237: 333346.

Gonçalves, E.G. \& Carneiro, D.J. 2003. Apparent digestibility coefficients of protein and energy of some ingredients used in diets for pintado, Pseudoplatystoma coruscans (Agassiz, 1829). Revista Brasileira de Zootecnia, 32: 779-786.

Guimarães, I.G., Pezzato, L.E. \& Barros, M.M. 2008. Amino acid availability and protein digestibility of several protein sources for Nile tilapia, Oreochromis niloticus. Aquaculture Nutrition, 14: 396-404.

Hajen, W.E., Higgs, D.A., Beames, R.M. \& Dosanjh, B.S. 1993. Digestibility of various feedstuffs by postjuvenile chinook salmon (Oncorhynchus tshawytscha) in seawater. 2. Measurement of digestibility. Aquaculture, 112: 333-348.

Hernández, C., Hardy, R.W., Márquez-Martínez, D.G., Domínguez-Jiménez, P.V. \& González-Rodríguez, B. 2015. Evaluation of apparent digestibility coefficients of individual feed ingredients in spotted rose snapper Lutjanus guttatus (Steindachner, 1869). Aquaculture Nutrition, 21: 835-842.

Ituassú, D.R., Pereira-Filho, M., Roubach, R., Crescêncio, R., Cavero, B.A.S. \& Gandra, A.L. 2005. Crude protein levels for juvenile pirarucu. Pesquisa Agropecuária Brasileira, 40: 255-259.

Kitagima, R.E. \& Fracalossi, D.M. 2011. Digestibility of alternative protein-rich feedstuffs for channel catfish, Ictalurus punctatus. Journal of the World Aquaculture Society, 42: 306-312.

Kraugerud, O.F., Penn, M., Storebakken, T., Refstie, S., Krogdahl, A. \& Svihus, B. 2007. Nutrient digestibilities and gut function in Atlantic salmon (Salmo salar) fed diets with cellulose or non-starch polysaccharides from soy. Aquaculture, 273: 96-107.

Krogdahl, Å., Penn, M., Thorsen J., Refstie, S. \& Bakke, A.M. 2010. Important antinutrients in plant feedstuffs for aquaculture: an update on recent findings regarding responses in salmonids. Aquaculture Research, 41: 333-344.

Lee, S.M. 2002. Apparent digestibility coefficients of various feed ingredients for juvenile and grower rockfish (Sebastes schlegeli). Aquaculture, 207: 7995.

Lima, R.L., Enke, D.B.S., Braun, N. \& Fracalossi, D.M. 2014. Redução de fósforo pela peneiragem da farinha de resíduos de peixes. Ciência Rural, 44: 1841-1844.

Lima, A.F., Rodrigues, A.P.O., Varela, E.S., Torati, L.S. \& Maciel, P.O. 2015. Pirarucu culture in the Brazilian Amazon: fledgling industry faces technological issues. Global Aquaculture Advocate, 18: 56-58.

Melo, G. \& Nikolik, G. 2013. Brazilian aquaculture. A seafood industry giant in the making. Rabobank Industry Note, 362: 1-11.

Mente, E., Deguara, S., Santos, M.B. \& Houlihan, D. 2003. White muscle free amino acid concentrations following feeding a maize gluten dietary protein in Atlantic salmon (Salmo salar L.). Aquaculture, 225: 133-147.

Naylor, R.L., Hardy, R.W., Bureau, D.P., Chiu, A., Elliott, M., Farrell, A.P., Forster, I., Gatlin, D.M., Goldburg, R.J., Hua, K. \& Nichols, P.D. 2009. Feeding aquaculture in an era of finite resources. Proceedings of the National Academy of Sciences, 106: 1510315110.

National Research Council (NRC). 2011. Nutrient requirements of fish and shrimp. The National Academies Press, Washington, D.C. 
Oliveira Filho, P.R.C. \& Fracalossi, D.M. 2006. Apparent digestibility coefficients of feed ingredients for jundia juveniles. Revista Brasileira de Zootecnia, 35: 15811587.

Park, H., Flores, R.A. \& Johnson, L.A. 1997. Preparation of fish feed ingredients: reduction of carotenoids in corn gluten meal. Journal of Agricultural and Food Chemistry, 45: 2088-2092.

Pereira-Filho, M. \& Roubach, R. 2010. Pirarucu (Arapaima gigas). In: Baldisserotto, B. \& Gomes, L.C. (Eds.). Espécies nativas para piscicultura no Brasil. Editora da UFSM, Rio Grande do Sul, pp. 27-56.

Refstie, S., Svihus, B., Shearer, K.D. \& Storebakken, T. 1999. Nutrient digestibility in Atlantic salmon and broiler chickens related to viscosity and non-starch polysaccharide content in different soybean products. Animal Feed Science and Technology, 79: 331-345.

Robaina, L., Moyano, F.J., Izquierdo, M.S., Socorro, J., Vergara, J.M. \& Montero, D. 1997. Corn gluten and meat and bone meals as protein sources in diets for gilthead seabream (Sparus aurata): nutritional and histological implications. Aquaculture, 157: 347-359.

Rodrigues, A.P.O., Gominho-Rosa, M.D.C., CargninFerreira, E., de Francisco, A. \& Fracalossi, D.M. 2012. Different utilization of plant sources by the omnivores jundiá catfish (Rhamdia quelen) and Nile tilapia (Oreochromis niloticus). Aquaculture Nutrition, 18: 65-72.

Santos-Cipriano, F., Lima, K.S., Bevitório-Passinato, E., Jesus, R.M., Magalhães-Júnior, F.O., Teles-Tonini, W.C. \& Tavares-Braga, L.G. 2015. Apparent digestibility of energetic ingredients by pirarucu juveniles, Arapaima gigas (Schinz, 1822). Latin American Journal of Aquatic Research, 43: 786-791.

Silva, T.S.C., Moro, G.V., Silva, T.B.A., Dairiki, J.K. \& Cyrino, J.E.P. 2013. Digestibility of feed ingredients for the striped surubim Pseudoplatystoma reticulatum. Aquaculture Nutrition, 19: 419-498.

Tacon, A.G.J. \& Metian, M. 2008. Global overview on the use of fish meal and fish oil in industrially compounded aquafeeds: trends and future prospects. Aquaculture, 285: 146-158.

Tacon, A.G.J., Metian, M. \& Hasan, M.R. 2009. Feed ingredients and fertilizers for farmed aquatic animals: sources and composition. Food and Agriculture Organi-zation of the United Nation (FAO). [http://www.fao.org/ docrep/012/i1142e/i1142e.pdf]. Reviewed: 17 July 2017.

Received: 8 March 2018; Accepted: 28 January 2019
Tibbetts, S.M., Milley, J.E. \&. Lall, S.P. 2006. Apparent protein and energy digestibility of common and alternative feed ingredients by Atlantic cod, Gadus morhua (Linnaeus, 1758). Aquaculture, 261: 13141327.

Van Soest, P.J., Robertson, J.B. \& Lewis, B.A. 1991. Methods of dietary fiber, neutral detergent fiber, and nonstarch polysaccharides in relation to animal nutrition. Journal of Dairy Science, 74: 3583-3597.

Vidal, L.V.O., Xavier, T.O., Michelato, M., Martins, E.N., Pezzato, L.E. \& Furuya, W.M. 2015. Apparent protein and energy digestibility and amino acid availability of corn and co-products in extruded diets for Nile tilapia, Oreochromis niloticus. Journal of the World Aquaculture Society, 46: 183-190.

Wang, J., Yun B., Xue, M., Wu, X., Zheng, Y. \& Li, P. 2012. Apparent digestibility coefficients of several protein sources, and replacement of fishmeal by a porcine meal in diets of Japanese seabass, Lateolabrax japonicus, are affected by dietary protein levels. Aquaculture Research, 43: 117-127.

Xavier, T.O., Michelato, M., Vidal, L.V.O., Furuya, V.R.B. \& Furuya, W.M. 2014. Apparent protein and energy digestibility and amino acid availability of commercial meat and bone meal for Nile tilapia, Oreochromis niloticus. Journal of the World Aquaculture Society, 45: 439-446.

Yu, H.-R., Zhang, Q., Cao, H., Wang, X.-Z., Huang, G.Q., Zhang, B.-R., Fan, J.-J., Liu, S.-W., Li, W.-Z. \& Cui, Y. 2013. Apparent digestibility coefficients of selected feed ingredients for juvenile snakehead, Ophiocephalus argus. Aquaculture Nutrition, 19: 139147.

Zhou, Z., Ren, Z., Zeng, H. \& Yao, B. 2008. Apparent digestibility of various feedstuffs for bluntnose black bream Megalobrama amblycephala Yih. Aquaculture Nutrition, 14: 153-165.

Zhou, Q.C., Tan, B.P., Mai, K.S. \& Liu, Y.J. 2004. Apparent digestibility of selected feed ingredients for juvenile cobia Rachycentron canadum. Aquaculture, 241: 441-451. 